\title{
IS LEARNING ENGLISH AT AN EARLIER AGE BETTER FOR INDONESIANS?
}

\author{
Muhammad Aminullah Hakiki, Laely Hidayati \\ University of New South Wales, Universitas Negeri Malang \\ mhakiki25@gmail.com, Laelyhidayati22@gmail.com
}

\begin{abstract}
In Indonesia, there exist many native languages which therefore position English as a foreign language following Bahasa Indonesia as the L2. This leads to the development of simultaneous bilinguals. However, there have been some contradictory opinions on whether learning English at an early age is effective as it can inhibit a child's L1 and L2 development. This may lead to the phenomenon of subtractive bilingualism resulting in a major dilemma for the government and parents. However, this notion can be debated through the critical period hypothesis. This paper presents a literature review on the age factor of learning English and its implication in Indonesia.
\end{abstract}

\section{Keywords: lingua franca, early bilingualism, Indonesian English learning}

Indonesia is an archipelagic country which consists of 13,000 islands. Due to this vast geographic area, the country consists of thousands of ethnicity and languages. However, out of the many languages spoken in Indonesia, the national language is Bahasa Indonesia. Bahasa Indonesia is used in every aspect of social life and therefore became the communication language for Indonesians. Therefore, most Indonesians are simultaneous bilinguals, speaking their native language first then introduced to Bahasa Indonesia but most Indonesian are considered sequential in terms of English acquisition as it is a foreign language. 
The acquisition of Bahasa Indonesia is easy as it is the main language in the country and a great amount of exposure to it helps the acquisition for the children. On the other hand, acquiring English is much more difficult as it is a foreign language (FL). As a matter of fact, the growing importance of English as an international language and as a global lingua franca is observable in virtually all the countries in the world in aspects such as education, politics, economy etc (Zacharias, 2006). Due to its importance, English has become a priority for the Indonesian government which is accessible by all social level (Zacharias, 2006). It is therefore no surprise that English is taught in the secondary schools as it can provide cultural experience and practical purposes for students that can be used in the future (Nababan, 1991). However, the question here is that whether it is too late or not to start learning English at secondary schools.

\section{EARLY CHILDHOOD BILINGUALISM}

There has been a general debate of the most effective stage of life in learning a language. The notion of learning a language early has become a well thought idea of the correct approach in language learning; however, there have been some contradictions to this statement. Hamers and Blanc (2000) state that languages learned informally before the age of six are generally mastered with native-like proficiency, whereas those learned in adolescence and adulthood will rarely attain a native-like level. Moreover, Taylor (1990, cited in Hamers and Blanc, 2000) states that learning a second language at a young age means that all the conditions favourable to first language acquisition are present, which is not the case for a later learned language. Such favourable conditions are that early 
language learners acquire language informally and in a more natural way whereas adolescents and adults learn language formally in schools or institutions.

There have been several researches conducted which support the claim that learning language early has a better effect on the proficiency. Ekstrand (1981) states that one greatest advantage of early bilingualism is that it allows a longer period of learning, starting at a time when the learner has to acquire less linguistic baggage in order to attain native like competence; this acquisition is, therefore, faster. Furthermore, Cummins (1984b, cited in Hamers and Blanc, 2000) state that there is a positive effect of age-of-arrival on proficiency among immigrants in which the younger the immigrants are, the higher their proficiency is. Moreover, Johnson and Newport (1989, cited in Hamers and Blanc, 2000) found that there is a linier correlation between age-of-arrival and their grammar for Korean and Chinese youngsters who had learned English before the age of 10, the same result was not present for those who arrived after puberty.

Moreover, early language learners seem to have the ability to acquire the phonological aspects better in such they can produce native-like. This ability of imitating a foreign accent will diminish by the age of eight (Tahta, Wood, \& Loewenthal, 1981, Hamers). It is also proven that early bilinguals have higher levels of awareness in phonology (Rubin \& Turner, 1989), syntax (Ben-Zeev, 1977a) and lexis (Diaz, 1985) compared to monolinguals meaning that exposing children at an early age will help them in the development of both. However, as late language learners, the children will learn language formally in schools and according to Snow \& Hoefnagel-Holhe (1978) late language learners are better L2 classroom learners than early language learners. Moreover, in a formal classroom 
situation older learners tend initially to learn quicker than younger learners (Singleton, 2003). This indicates that late language learners have an initial faster rate in their second language development than early learners. Maybe the only disadvantage that late language learners have is that they will not have a nativelike proficiency in the sense that they will not have a native-like accent. This perspective on viewing language development through age is further related to the critical period hypothesis.

\section{CRITICAL PERIOD HYPOTHESIS}

The critical period hypothesis states that linguistic development needs to be activated between 3-12 years of age for normal development to occur (Lenneberg, 1967, cited in Hamers and Blanc). This implies that if a person is to learn language beyond this period, the chance for the person to acquire a language will get much harder. However, the hypothesis lacks empirical evidence and is a controversial issue in bilingualism and second language acquisition. However, if we relate this hypothesis to the human biological development, especially the brain, it may give us a clearer idea of the hypothesis. Woods \& Carey (1979) state that children recover more quickly and more fully from aphasia than adults and this is because the brain of a child is not yet fully developed whereas the adult brain has fully developed. This means that the child's brain has a greater plasticity compared to the adult's brain; therefore other parts of the brain can take over the functions of the damaged one (Hoff, 2014). Moreover, Penfield \& Roberts (1959, cited in Hamers and Blanc, 2000) assume that an early language learner's ability to learn a language with ease is because of the relatively greater cerebral plasticity 
that the child has. In sense to this, an early language learner's brain has not neurologically matured thus giving the learner greater flexibility in learning a language and making the learner easier in acquiring it as he or she has less linguistic baggage.

\section{INTRODUCING ENGLISH TO INDONESIAN FAMILY CONTEXT}

In Indonesia, the government has acknowledged English as a priority language to be acquired. However, introducing English at secondary level might not be the best approach. Here, what is referred to as learning at an earlier age is around the age of 4 whereas secondary schools start at around the age of 12 years old and can be considered as a late language learner. Based on the previous explanations of early and late language learners and the critical period hypothesis, it can be said that there is no definite answer whether introducing and providing language learning at secondary level is too late or not. However, it is clear that there is more good than harm in introducing a child to English earlier in life. So, even though late language learners can succeed in language learning, it is suggested if possible that Indonesian parents facilitate their children to learn English language at an earlier age as it is not harmless towards their first language development.

This idea of introducing English at the early stage is supported by Cummin's interdependence hypothesis (1979). He mentions that there is a common underlying proficiency that can be affected by the development in either language. This means that when a child is learning two languages simultaneously, the development of his/her first language can affect the development of the second 
language and vice versa. Cummin's idea is empirically supported by the study conducted by Holmstrand (1979) in Sweden. This study showed that elementary students who already had a high competence in their mother tongue and who started to learn a foreign language at an early age would improve their competence in their mother tongue more than peers who did not have exposure to a foreign language. This means that the presence of a second language can positively influence the development of the first language and vice versa. However, there are still dilemmas Indonesian parents in choosing at what stage they should start facilitating their children in learning a second language.

The dilemma faced by the Indonesian parents is that the introduction of English at an early age will threaten Bahasa Indonesia and may cause subtractive bilingualism. Subtractive bilingualism is the process of valorizing the second language at the expense of the first language which may lead to the loss of the first language (Hamers \& Blanc, 1989). Introducing English at an early age means that parents have to enrol their children at preschool, in this case, international preschool which is available in Indonesia. Such school type is the only school that can expose children between the age of 3-5 to English. Manara (2014) in her study analyzed the teacher's perspective in teaching at an international school in Indonesia and how it influences the child's first and second language. Here, one of her participants mentioned that English is used as the medium of instruction (MOI) in all courses from the very beginning as they enter the international school and also used for social communication outside the classroom. This type of school encourages the use of the second language as the dominant institution language and to some extent abandons the student's first language which may lead to 
subtractive bilingualism (Garcia, 2009). This early introduction to English worries the parents as children may lose proficiency in the first language (Bahasa Indonesia) due to early exposure of English. In this case, the parents' role in maintaining both of their child's language development is crucial.

The role of the parents here is to maintain their child's first language (Bahasa Indonesia) and as the parents are native speakers of the language, they can communicate with their children in Bahasa Indonesia at home and not shift to using English for communication, therefore, valorizing the first language. Today, this may not be much of a problem in the Indonesian context as not many Indonesian parents have the ability to speak in English. However, for future purposes it is important as a reminder towards parents. Therefore, emphasizing this matter is important due to the importance in regards to the valorization of a language. According to Hamers \& Blanc (2000) valorization is giving value to language as a functional tool. If the surrounding of the child is valorizing a certain language, the child must valorize it as well to be able to communicate with the surrounding. Furthermore, valorization of the language provides the children to build up the social psychological mechanisms relevant to their linguistic and social development (Hamers \& Blanc, 2000). This means that it can give the opportunity for the children to have a positive relationship with the language and find meaning to the use of the language. If this is to be achieved, the two main functional aspects of language; the communicative and the cognitive develops within the children due the adequate environment (Hamers \& Blanc, 2000). Furthermore, valorization of the language gives extra motivation for the child to be proficient in the language as it has certain values within his social network. 
Since both languages are valorized in different context, the first language at home and the second language at school, there should be no problem in the language development of both languages if English is to be learnt at earlier age. Moreover, learning two languages at the same time will benefit the child in both language development as mentioned through the interdependence hypothesis.

\section{CONCLUSION}

In conclusion, there is no fine line in determining whether exposing children to language early or late brings more success. Learning a language early often leads to higher language proficiency but it does mean that they are better than late language learners. However, what can be said is that facilitating a child to learn a second language at earlier age brings more good than harm. To put out the worries of Indonesian parents in exposing their children to early exposure of English, they have to be aware that they have a significant role to play in which they must valorize the first language at home so that it does not lead to language shift and subtractive bilingualism.

\section{REFERENCES}

Ben-Zeev, S. (1977). Mechanisms by which childhood bilingualism affects understanding of language and cognitive structures. In P. A. Hornby (ed). Bilingualism: Psychological, Social, and Educational Implications. New York: Academic Press.

Cummins, J. (1979). Linguistic interdependence and the educational development of bilingual children. Review of Educational Research, 49, 221-251.

Cummins, J. (1984a). Bilingualism and special education: Issues in assessment and pedagogy. Clevedon: Multilingual Matters, 6 . 
Cummins, J. (1984b). Wanted: a theoretical framework for relating language proficiency to academic achievement among bilingual students. In C. Rivera (ed.) Language proficiency and academic achievement. Clevedon: Multilingual Matters.

Diaz, R. M. (1985). Bilingual cognitive development: addressing the gaps in current research. Child Development, 56, 1376-1388.

Ekstrand. L. H. (1981). Theories and facts about early bilingualism in native and migrant children. Grazer Linguitische Studien, 14, 24-52.

Hamers, J.F. and Blanc, M.H.A. (2000). Bilinguality and Bilingualism 1st Edition. Cambridge University Press

Hamers, J.F. \& Blanc, M.H.A. (2000). Bilinguality and bilingualism. 2th edn. Cambridge: Cambridge University Press.

Hoff, E. (2014). Language development. 5th edn. Wadsworth: Cengage Learning.

Garcia, O. (2009). Bilingual education in the 21st Century: A global perspective. West Sussex, UK: Wiley-Blackwell.

Holmstrand, L. E. (1979). The effects on general school achievement of early commencement of English instruction. University of Upssala Department of Education, Upssala Reports on Education, 4, 1-45.

Johnson, J. S. \& Newport, E. L. (1989). Critical effects in second language learning: the influence of maturational state on the acquisition of English as a second language. Cognitive Psychology, 21, 60-99.

Lenneberg, E. H. (1967). Biological Foundations of Language. New York: Wiley.

Manara, C. (2014). "That's what worries me": Tension in English language education in today's Indonesia. International Journal Innovation in English Language, 3(1), 21-35.

Nababan, P. W. J. (1991). Language in education: The case in Indonesia. International Review of Education. 37(1), 115-131.

Penfield, W. P. \& Roberts, L. R. (1959). Speech and Brain Mechanism. London: Oxford University Press.

Rubin, H., \& Turner, A. (1989). Linguistic awareness skills in grade one children in a French immersion setting. Reading and Writing: An Interdisciplinary Journal, 1, 73-86. 
Singleton, D. (2003). Critical period or general age factor(s)? In M. D. P. G. Mayo and M. L. G. Lecumberri (ed). Age and the acquisition of English as a foreign language. Clevedon: Multilingual Matters Ltd.

Snow, C. E. \& Hoefnagel-Hohle, M. (1978). The critical period for language acquisition: evidence from second language learning. Child Development, 49, 1114-11128.

Tahta, S., Wood, M., \& Lowenthal, K. (1981). Age changes in the ability to replicate foreign pronunciation and intonation. Language and Speech, 24, 363-372.

Taylor, I. (1990). Psycholinguistics: Learning and using language. Englewood Cliffs, NJ: Prentice Hall.

Woods, B. T., \& Carey, S. (1979). Language deficits after apparent clinical recovery from childhood aphasia. Annals of Neurology, 6, 405-409.

Zacharias, N. (2006). Native or non-native teachers: A study on tertiary teacher's beliefs in Indonesia. Collected Essays on Learning and Teaching, Vol. 6, 47-62. 